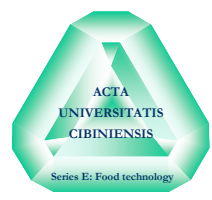

\title{
STUDY ON THE INDUSTRIAL CLUSTER OF TROPICAL BANANAS BASED ON GEM MODEL
}

\author{
- Research paper -
}

Qiong YANG

\author{
Hunan Vocational College of Science and Technology, Changsha, Hunan, 410004, China.
}

Qiong Yang, Hunan Vocational College of Science and Technology, Room. 1603, 2rd Building, Ceng Shang Guan Di, Puyuan Shuizhu Avenue, Tianxin District, Changsha City, Hunan, China

\begin{abstract}
China. As a main producing area of bananas, the Hainan Ledong Industrial Cluster's competitiveness is of great significance to the development of the whole banana industry in China. This paper first analyzed the cultivation of tropical banana and the market share of bananas in each region, and then analyzed the competitiveness of Ledong banana industry cluster through the GEM (Groundings- Enterprises- Markets) model. The results showed that the GEM model score was 456 points, and the domestic cluster competitiveness exceeded the average level. The "factor pair" socre suggested that the scores of the structure, strategy and competition of the enterprise were low, which restricted the development of Ledong banana industry cluster.
\end{abstract}

Keywords: GEM model, tropical banana, cluster competitiveness, industrial cluster

\section{INTRODUCTION}

Because of its sweet taste, rich trace elements and vitamins and high nutritional value, medical value and economic value, banana enjoys a good reputation of "happy fruit". China is one of the oldest countries in the world to cultivate bananas. Ledong County in Hainan Province is known as the "hometown of Chinese bananas" and its tropical banana industry has begun to take shape. The development of Ledong banana industry has led the development of the transport, packaging, fertilizer industries, forming a Ledong banana-led industrial cluster. Glover D et al (Glover et al., 2014) thought that the Latin American banana industry had undergone major transformations over the last hundred years, resulting from the strategies of Transnational Corporations (TNCs), changes in relative factor prices, political conditions, and technological change. He Linning et al (He et al., 2013) learned from the experience of the outstanding industrial clusters in the United States and analyzed the feasibility of building a tropical fruit industry cluster in China. Sinngu (Sinngu, 2014) used Michael
Porter's competitive diamond framework to determine and analyze the factors influencing the performance and competitive success of the domestic citrus fruit industry. GEM model (Pang, 2015) in an improvement based on the diamond model (Bakhshinejad, 2014) which takes the regional industry as the object of analysis and makes a comprehensive evaluation of the competitiveness of industrial clusters.

Applying the GEM model, this paper studies the tropical banana industry cluster in Ledong area from the three factors of grounding, enterprise and market. There is a certain correlation between each two factors and the situation of industrial clusters can be fully reflected through the six factors of the GEM model. Though with good natural resources, traffic conditions, policy support and market prospects, Ledong banana industry cluster is still inadequate in capital resources, deep processing technology and brand building. Besides, attention should be paid to banana pest problems. The tropical banana industry cluster research based on the GEM model contributes to a comprehensive analysis of the competitiveness of industrial clusters to make

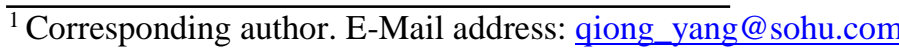


corresponding adjustment. The elements are required to form a joint force so as to better activate the development of industrial clusters,

\section{MATERIALS AND METHODS}

\section{TROPICAL BANANA CULTIVATION AND INDUSTRIAL CLUSTERS}

\section{Development of tropical banana planting industry}

Banana, a musaceae musa fruit, is rich in trace elements and vitamins, with excellent therapeutic nutritional value and a certain pharmacological effect. Growing well in deep and loose soil with good drainage in hot and humid areas ( Zhong et al., 2014), bananas have the characteristics of fast growth, early production and high yield, and have significant economic benefits at home and abroad. In the selection of banana varieties, the ones which well adapt to the local environment should be selected. Based on this, good quality seedlings should be first considered. According to the planting time, soil preparation should be finished in advance for ploughing and sowing. Field planting should be reasonably arranged and appropriate planting time and density should be determined. Bananas are not resistant to wind, thus daily wind and cold prevention work should be emphasized. The good cultivation of tropical bananas ensures the safety of the ecological environment, improves the yield and quality of bananas, thereby enhancing the comprehensive competitiveness of tropical banana industry cluster.

As shown in Table 1, the total area of Chinese banana in 2016 was more than 6 million mu. Although the banana cultivation area in Hainan Province was only about 0.8 million $\mathrm{mu}$, its share in the domestic market was as high as $80 \%$, suggesting that Hainan Province is China's tropical banana industrial cluster area, which not only has advantages in production but also develops rapidly in processing, computing and sales, with an evident industry gathering degree.

\section{Development of Ledong banana industry cluster}

Industrial cluster (Håkon, 2014) is a group composed of enterprises, specialized suppliers, service providers, financial institutions, related thereby enhancing the overall competitiveness of industrial clusters.

industrial manufacturers and other associative institutions concentrated in a certain area, with competitive and cooperative relationships. The Ledong banana industry cluster is a bananadominated space cluster which connects the upstream and downstream industries and related institutions, taking packaging, logistics, fertilizer and other enterprises close cooperation as the starting point.

Table 1 Banana cultivation and market share in Chinese provinces in 2016

\begin{tabular}{|l|l|l|l|}
\hline Area & $\begin{array}{l}\text { Planting } \\
\text { area (mil. } \\
\text { mu) }\end{array}$ & $\begin{array}{l}\text { Annual } \\
\text { production } \\
\text { (mil. tons) }\end{array}$ & $\begin{array}{l}\text { Market } \\
\text { share } \\
(\%)\end{array}$ \\
\hline Hainan & 0.8 & 2.5 & 82 \\
\hline Yunnan & 1.76 & 2.8 & 5 \\
\hline $\begin{array}{l}\text { Guang- } \\
\text { dong }\end{array}$ & 1.12 & 2.2 & 3 \\
\hline Guangxi & 1.85 & 3 & 8 \\
\hline Fujian & 0.62 & 2 & 2 \\
\hline Total & 6.15 & 12.5 & 100 \\
\hline
\end{tabular}

Ledong, located in the southwest of Hainan Province, is one of the few tropical regions in China, with the world's most suitable natural environment-fertile land, adequate light and abundant rainfall, for the development of banana production. Ledong banana, known as one of "China's top ten tropical fruit", has long been praised in the domestic and foreign markets because of its strong flavor, good taste, good quality and high nutrition. In recent decades, increasing importance has been attached to the development of the Ledong banana industry and a lot of banana villages have emerged in Ledong County, which promotes its banana industry to gradually embark on the base, large-scale and industrial development path. The degree of concentration of the banana industry can be calculated through location quotient (상호, 2015). From 2010 to 2016, the location quotient of the banana industry in Ledong area was greater than 1 , and it was increasing year by year, which shows that the banana industry in Ledong has its advantages in scale and strong competition ability. At present, Ledong bananas show a trend of in-depth clustering. In 
terms of production, Ledong bananas are continually promoted on breed optimization and production standardization. Ledong County actively introduced Brazilian banana (De et al., 2016), Williams 8818 (Tourky et al., 2014) and other varieties of bananas and made corresponding promotion, greatly improving the production of bananas in the area. Besides, a high technological content standardization production demonstration base was built up,

\section{ANALYSIS OF TROPICAL BANANA INDUSTRY CLUSTER UNDER GEM MODEL}

\section{Ledong Banana Industrial Cluster Based on GEM Model}

The GEM (Groundings- Enterprises- Markets) model is an improved model for analyzing the competitiveness of enterprise clusters based on the diamond model, which was put forward by two Canadian scholars Tim Padmore and Henrev Gibson. Compared with other models, the advantage of the GEM model is that it can be more reasonable in quantitative evaluation and analysis. The opinions of industry cluster experts and scholars and related enterprises are collected in the quantitative analysis (Motoiu et al., 2016) process so that the advantages and disadvantages of industrial clusters can be accurately described. The GEM model contains three pairs of factors, which are groundings, enterprises and markets. The calculation of the "factor pair" score of model quantification is as follows:

PAIR SCORE $=\left(D_{2 i-1}+D_{2 i}\right) / 2, \quad i=1,2,3$

Note: $D_{2 i-1}$ and $D_{2 i}$ are the scores of each factor; the two factors in "factor pairs" can be substituted for each other.

Multiply the "factor pairs" score, and the linear cluster score can be obtained:

LINEAR CLUSTER SCORE $=\prod_{i=1 \sim 3}\left(D_{2 i-1}+D_{2 i}\right) / 2$

Set the full score to be 100 and carry out a ratio conversion, as follws:

$\mathrm{GEM}=2.5\left(\Pi_{i=1 \sim 3}\left(D_{2 i-1}+D_{2 i}\right)\right)^{2 / 3}$

If a cluster has a score of around five (up to the average), then its GEM score is around 250, indicating that the competitiveness of the cluster reaches the domestic average; If all factors' score is close to 10 , then the GEM score of competitiveness of the enterprise which led the level of agricultural standardization. In terms of sales, with natural climatic conditions, Ledong bananas have an absolute time advantage which enables them to stagger the time to market of bananas in other main producing areas. Ledong bananas not only have a good domestic market but also are exported overseas. With its brand awareness and influence rising, Ledong bananas have become a national brand.

cluster will be close to 1000 , indicating that the competitiveness of this industry cluster is world-class.

\section{Background aspect}

The Ledong region has excellent climatic conditions and abundant land resources. Its tropical monsoon climate is characterized by abundant light, rich heat, adequate rainfall, light breeze and no frost, which are all favorable conditions for the growth of bananas to ensure their quality. The rich labor resources in the region also contribute to the development of its tropical banana industrial cluster. The region locates between Sanya, the tourist city, and eight industrial areas, the three of which are connected by railways and highways, and is close to the port and airport, which forms a land, sea and air threedimensional transport network. Hence, the region has a good location and convenient transportation.

With the development of its banana industry, Ledong's irrigation system is becoming more and more complete. Most areas have been equipped with communication networks to strengthen the link between the main bodies, which is beneficial to the development of the banana industry cluster. The Ledong local government supports and attaches great importance to its tropical banana industry development and has introduced a series of industrial development policies and production technology standards as well as formed a set of scientific management standards. However, there are still problems such as pests and diseases, inadequate capital resources and imperfect infrastructure, etc.

\section{Enterprise aspect}

With the continuous development of its tropical banana industry, its banana planting area has expanded year by year. At present, the 
banana planting area of the whole county is about 12 million mu, realizing the transformation from sporadic distributed and decentralized cultivation to regionalization, scale and industrial belt cultivation. Meanwhile, with the continuing improvement of its production organization forms, a variety of combos have been formed. The county has also completed a banana standardized production demonstration base to enhance the production capacity and quality of bananas. And the development of the banana industry cluster also drives the development of transport, packaging, cardboard boxes, fertilizer, plastics and other related industries. Nevertheless, the development of banana deep processing in the region lags behind, with loose organizational structure and imperfect preservation technology, and is limited only to primary processing such as banana slices.

\section{On market aspect}

As for the market aspect, the annual total output of Ledong bananas reaches 300,000 tons, and the total output value is up to 700 million yuan. Despite a high market share within Hainan province, Ledong bananas are also sold to large and medium-sized cities such as Beijing and Shanghai and Hong Kong and Macao regions. At the same time, it also establishes trade relations with Japan, the United States, Russia and other countries and is sold overseas. Still, the Ledong banana industrial cluster has not yet formed brand effect.

\section{Evaluation Analysis of GEM model factors of Ledong banana}

Based on the GEM model, this paper analyzes the industrial clusters of Ledong banana. The weight of each factor in the GEM model is determined through the Analytic Hierarchy Process (Durbach, et al., 2014) and the objective evaluation on each factor made by experts based on questionnaire forms are collected. Then, statistical calculation is carried out on all the data obtained. Table 2 shows the weight and score obtained by the hierarchy analysis.

Table 2 Analytic analysis of GEM model factors of Ledong 's banana

\begin{tabular}{|c|c|c|c|c|}
\hline Factor pair & $\begin{array}{l}\text { Level } 1 \\
\text { indicators }\end{array}$ & Level 2 indicators & $\begin{array}{l}\text { Weight } \\
w_{i}\end{array}$ & Score \\
\hline \multirow[t]{6}{*}{ Groundings } & \multirow{4}{*}{ A Resources } & A1 Geographic traffic conditions & 0.413 & \multirow[t]{4}{*}{7.514} \\
\hline & & A2 Natural resources & 0.372 & \\
\hline & & A3 Labor resources & 0.215 & \\
\hline & & B1 Planting infrastructure & 0.357 & \\
\hline & \multirow[t]{2}{*}{ B Infrastructure } & B2 Political support services & 0.408 & \multirow[t]{2}{*}{7.111} \\
\hline & & B3 Industry associations' organize services & 0.235 & \\
\hline \multirow[t]{6}{*}{ Enterprises } & \multirow{3}{*}{$\begin{array}{l}\text { C Suppliers and } \\
\text { related } \\
\text { companies }\end{array}$} & C1 Supplier strength & 0.454 & \multirow[t]{4}{*}{6.542} \\
\hline & & C2 Logistics and transport industry & 0.277 & \\
\hline & & C3 Packaging services & 0.269 & \\
\hline & \multirow{3}{*}{$\begin{array}{l}\text { D Enterprise } \\
\text { structure, } \\
\text { strategy and } \\
\text { competition }\end{array}$} & D1 Enterprise human resources & 0.344 & \\
\hline & & D2 Enterprise strategy development & 0.212 & \multirow{2}{*}{5.573} \\
\hline & & $\begin{array}{l}\text { D3 Inter - enterprise communication and } \\
\text { cooperation }\end{array}$ & 0.444 & \\
\hline \multirow[t]{6}{*}{ Markets } & \multirow{3}{*}{ E Local market } & E1 Local market share & 0.221 & \multirow[t]{3}{*}{7.373} \\
\hline & & E2 Local market prospects & 0.257 & \\
\hline & & E3 Local customer trust & 0.522 & \\
\hline & \multirow{3}{*}{$\begin{array}{l}\text { F External } \\
\text { market }\end{array}$} & F1 Foreign market share & 0.394 & \multirow{3}{*}{6.516} \\
\hline & & F2 Foreign market prospects & 0.333 & \\
\hline & & F3 Foreign market promotion obstacles & 0.273 & \\
\hline
\end{tabular}

From table 2, the "factor pair" score can be obtained:

Groundings: PAIR SCORE $=(A, B) / 2=(7.514+7.111) / 2=7.3125$ 
Enterprises: PAIR SCORE $=(C, D) / 2=(6.542+5.573) / 2=6.0575$

Markets: PAIR SCORE $=(E, F) / 2=(7.373+6.516) / 2=6.9445$

Then, the "linear cluster score" and GEM model score can be calculated as follows:

$$
\begin{aligned}
& \text { LINEAR CLUSTER SCORE }=\Pi_{i=1 \sim 3}\left(D_{2 i-1}+D_{2 i}\right) / 2 \\
& \begin{aligned}
\mathrm{GEM} & =2.5\left(\Pi_{i=1 \sim 3}\left(D_{2 i-1}+D_{2 i}\right)\right)^{2 / 3}=2.5 \times((A+B) \times(C+D) \times(E+F))^{2 / 3} \\
& =2.5 \times((7.514+7.111) \times(6.542+5.573) \times(7.373+6.516))^{2 / 3} \\
& =2.5 \times(2460.8791)^{2 / 3}=455.68725 \approx 456
\end{aligned}
\end{aligned}
$$

Through the calculation, we get the competitiveness of Ledong banana industry cluster, and the scale of each index is shown in Figure 1. Its GEM model score is 456, indicating that the banana industry has exceeded the domestic average level, and its cluster competitiveness is relatively high in the country. The "factor pair" score of the model is: groundigns: 7.3125; enterprises: 6.0575; markets: 6.9445 . The Ledong banana industry cluster now has strong market competiti- veness, but the advantage is not obvious compared with the top domestic enterprises (with their GEM total score reaching around 640). The highest score of resource index in the industrial cluster shows that resources are key elements in the process of industrial cluster formation. The scores of enterprise structure, strategy and competition indicators are low, which have obviously restricted the development of the industrial cluster.

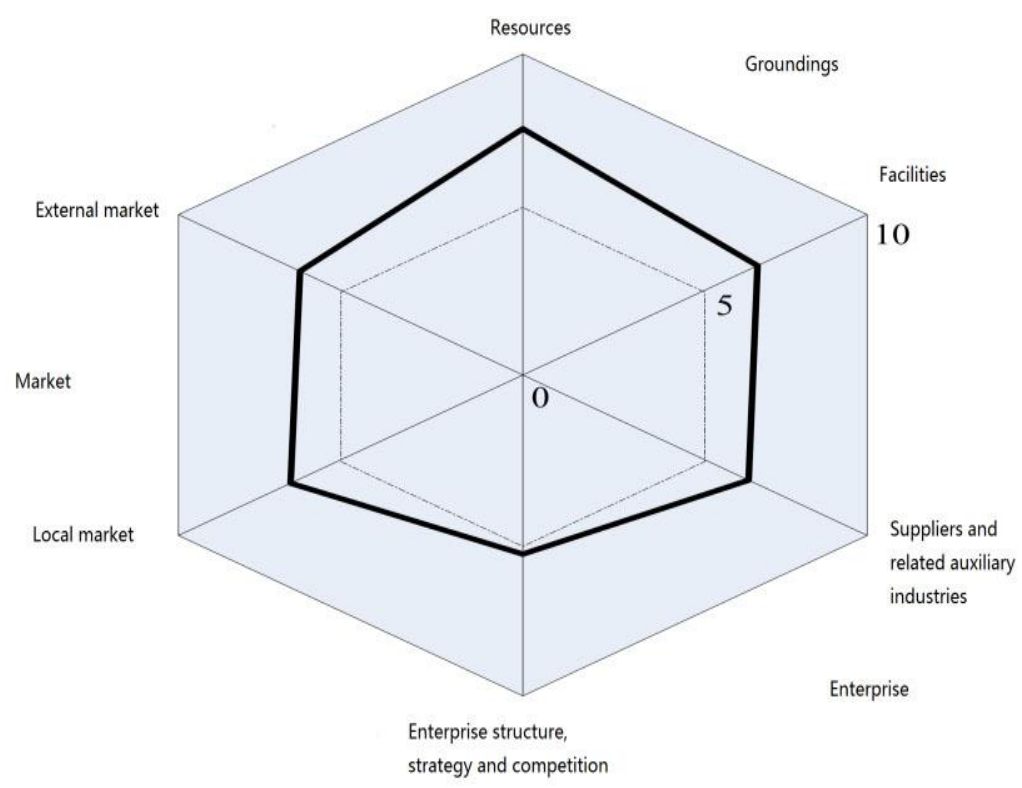

Figure 1. Various factors' index score of the GEM model

\section{DISCUSSION}

Based on the GEM model, this paper studies the tropical banana industry cluster in Ledong, Hainan Province, analyzes the present situation and advantages and disadvantages of the tropical banana industry cluster, and puts forward the corresponding improvement suggestions.

As can be seen from the above, Ledong's banana industry cluster has great development prospects in market share and competitiveness, with obvious resource and background advantages. However, there are large deficiencies in the business factors of Ledong banana industry. For the deep processing level problem of enterprises, it is recommended that enterprises develop deep processing of agricultural products such as banana juice, banana preserved fruit and banana jam on the basis of ensuring the quality of bananas and the safety of the processing technology so as to extend the industrial chain (Lyons et al., 2014) and achieve the diversification of banana consumption patterns. The innovation capability and cooperation level of the enterprises within the cluster are insufficient, which requires the leading role of leading enterprises ( $\mathrm{Li}$ et al., 2014) to increase investment in scientific research, to develop new technologies as well as new products, to promote the concentration of innovative 
elements and focus on service, and to enhance the overall technology level, and strengthen the development of farmer professional cooperatives, improve the degree of farmer's organization, and thus enhance the radiation effect of the entire industry. Regional brand (Stoklasa et al., 2016) is the regional

\section{CONCLUSIONS}

In this paper, through the study of the industrial clusters of Ledong bananas, which are the most popular among consumers, we analyzed the advantages and disadvantages of the tropical banana industry clusters through the GEM model and the level evaluation method. In addition, suggestions were put characteristics and overall image of a region. A good regional brand image can have a positive effect, enhance the overall image of the industry cluster in the region and win both the reputation and market. Therefore, it is very important to strengthen the construction of regional brands.

forward for the problems existing in the banana industry clusters, which could promote the development of the tropical banana industrial clusters. Nevertheless, since there is no introduction of other banana industry clusters for comparative analysis, there is a lack of depth in the suggestions, which needs to be further improved in future researches.

\section{REFERENCES}

1. Bakhshinejad M. (2014). Porter's Competitive Advantage Model and its Application in Bottled Drinking Water in Iran. Agricultura Tropica Et Subtropica, 47(2):60-67. DOI : 10.2478/ats-2014-0008.

2. De B M C, Leonel M \& Franco C M. (2016). Characterization of banana starches obtained from cultivars grown in Brazil. International Journal of Biological Macromolecules, 89:632-639. DOI: 10.1016/j.ijbiomac.2016.05.040.

3. Durbach I, Lahdelma R \& Salminen P. (2014). The analytic hierarchy process with stochastic judgements. European Journal of Operational Research, 238(2):552 - 559. DOI: 10.1016/j.ejor.2014.03.045.

4. Glover D \& Maldonado C L. (2014). Changing Comparative Advantage, Short Term Instability and Long Term Change in the Latin American Banana Industry. Canadian journal of Latin American and Caribbean studies, 16(32):91-108. DOI: 10.1080/08263663.1991.10816665.

5. He L N, Xu R S \& Sun G L. (2013). Drawing on the experience of American grape industry cluster to build Guangxi tropical fruit industry cluster. Guangxi economy, (11):48-51.

6. Håkon H. (2014). Methodology for enterprise development and for creation of industrial cluster. 25th International Conference on Software Engineering and Knowledge Engineering (SEKE), 2009-10-012009-10-02 (7102-7107). Esbjerg, Denmark: SINTEF Technology and Society, Applied Economics and Operations Research.

7. Li Kai, Niu J \& Huang J C. (2014). Research on development of leading enterprise under the policy of agriculture industrialization in China. Agriculture and Food Economics Research, 60:27-38.

8. Lyons A C \& Ma' Aram A. (2014). An examination of multi-tier supply chain strategy alignment in the food industry. International Journal of Production Research, 52(7):1911-1925. DOI: 10.1080/00207543.2013.787172.

9. Motoiu E, Pavel O A \& Lakatos E S. (2016). A brief quantitative analysis of clusters from the creative industry in Romania. Review of Applied Socio-Economic Research, 11(1/ 2016):57.

10. Pang W. (2015). Analysis of Agricultural Industrial Clusters Based on GEM Model - A Case Study of Nanchong City, Sichuan Province. Modern commerce industry, (25):9-11.

11. Sinngu T. (2014). Determinants of Competitiveness in the South African Citrus Fruit Industry. Strategic Management Journal, 35(7):995 - 1012.

12. Stoklasa M, Starzyczna H. (2016). Regional brand benefits for companies - Comparison of 2013 and 2015/6. Xix. Mezinárodní Kolokvium O Regionálních Vě dách. Sborník Př íspě vk. 2016:210-217.

13. Tourky M N, Tarabih M E \& El-Eryan E E. (2014). Physiological Studies on the Marketability of Williams Banana Fruits. American Journal of Plant Physiology, 9(1):1-15. DOI: 10.3923/ajpp.2014.1.15.

14. 이상호. (2015). An Analysis on the Regional Location Quotient for Fruit Vegetables. 11(6):349-359. DOI: 10.16980/jitc.11.6.201512.349.

15. Zhong S, Mo Y, Guo G, et al. (2014). Effect of continuous cropping on soil chemical properties and crop yield in banana plantation. Journal of Agricultural Sciwence and Tehcnology, 16(1):239-250. 